\section{Drip Application of Alternative Fumigants to Methyl Bromide for Strawberry Production}

\author{
Husein A. Ajwa ${ }^{1}$ \\ University of California-Davis, Department of Vegetable Crops, 1636 East \\ Alisal Street, Salinas, CA 93905.
}

\section{Thomas Trout \\ U.S. Department of Agriculture, AgriculturalResearch Service, Water Management Research Laboratory, 9611 South Riverbend, Parlier, CA 93648}

\begin{abstract}
Strawberry (Fragaria $\times$ ananassa Duchesne) is a high-value cash crop that benefits from preplant soil fumigation with methyl bromide (MB) and chloropicrin (CP). Methyl bromide will be banned in the U.S. and other developed countries by 2005 for most uses. Potential alternative chemicals to replace methyl bromide for soil fumigation include CP, 1,3-dichloropropene (1,3-D), and methyl isothiocyanate (MITC) generators such as metam sodium (MS). Commercial formulations of these fumigants applied singly and in combination through drip irrigation systems were evaluated at two sites for three consecutive growing seasons as alternatives to $\mathrm{MB}$ : $\mathrm{CP}$ fumigation for strawberry production. $\mathrm{A}$ mixture of 1,3-D and CP was shank injected as Telone C35 (62\% 1,3-D and 35\% CP) at $374 \mathrm{~kg} \cdot \mathrm{ha}^{-1}$. An emulsifiable concentrate (EC) formulation of 1,3-D and CP was applied as InLine $(60 \%$ 1,3-D and $32 \% \mathrm{CP})$ at 236 and $393 \mathrm{~L} \cdot \mathrm{ha}^{-1}$ through drip irrigation systems in three amounts of irrigation water $\left(26,43\right.$, and $\left.61 \mathrm{~L} \cdot \mathrm{m}^{-2}\right)$. Chloropicrin $(\mathrm{CP}$ EC, $96 \%)$ was drip applied singly at 130 or $200 \mathrm{~L} \cdot \mathrm{ha}^{-1}$. Metam sodium was applied singly as Vapam HL in three amounts of water and in combination with InLine and CP EC. Strawberry growth, fruit yields, disease pressure, and weed biomass were compared to an untreated control and shank injection with MB:CP mixture (67:33) at $425 \mathrm{~kg}^{\cdot \mathbf{h a}^{-1}}$. For soils high in pathogen populations, fruit yield from the untreated plots was $34 \%$ to $50 \%$ relative to the MB:CP treatment. The greatest $(95 \%$ to $110 \%)$ yields relative to MB: CP were in the high rates of the InLine treatments. Yields from simultaneous drip fumigation with a combination of Vapam HL and InLine or CP EC were less (67\% to $79 \%)$ than yields from shank fumigation with MB:CP due to 1,3-D and CP hydrolysis reactions with Vapam HL or the generated MITC in the irrigation water that reduced the efficacy of these combinations to control soilborne pathogens. Application of reduced rates of InLine or CP EC followed 6 days later with reduced rates of Vapam HL controlled soil borne pathogens and weeds and produced the greatest fruit yield relative to all treatments. Chemical names used: 1,3-dichloropropene (1,3-D); methyl bromide (MB); trichloronitromethane (chloropicrin, CP); sodium methyldithiocarbamate (metam sodium); methyl isothiocyanate (MITC).
\end{abstract}

California produces $>80 \%$ of total U.S. strawberry (Fragaria $\times$ ananassa Duchesne) with $770,000 \mathrm{Mg}$ of strawberries produced annually, valued at $\$ 1$ billion (USDA, 2003). The California Strawberry Commission (2003) estimated that more than 11,430 hectares were planted to strawberry in 2003. Preplant soil fumigation with $\mathrm{MB}$ in combination with chloropicrin $(\mathrm{CP})$, plastic mulching, integrated pest management, drip irrigation, and fertiga-

Received for publication 8 Dec. 2003. Accepted for publication 26 Jan. 2004. The authors thank Steve Fennimore for weed control evaluation and Frank Martin, John Duniway, and Krishna Subbarao for their help with soilborne pathogen evaluation. Thanks to Frank Westerlund and Christopher Winterbottom, California Strawberry Commission, for their assistance in conducting this research. This project was funded by the USDA-ARS, Water Management Research Laboratory, Parlier, Calif. Mention of trade names or proprietary products is for the convenience of the reader only, and does not constitute endorsement or preferential treatment by USDA-ARS or the Univ. of California.

${ }^{1}$ Corresponding author; e-mail haajwa@ucdavis. edu.

tion have played important roles in the stability of strawberry production in California. Over $95 \%$ of the strawberry land is fumigated with $\mathrm{MB}: \mathrm{CP}$ mixtures (MB plus $2 \%$ to $45 \% \mathrm{CP}$ ) at 300 to $450 \mathrm{~kg} \cdot \mathrm{ha}^{-1}$ (California EPA, 2002). The strawberry industry has favored the use of $\mathrm{MB}$ in combination with $\mathrm{CP}$ because of the synergistic effects of these two chemicals to control verticillium wilt (Verticillium dahliae Kleb.) and other soilborne pathogens and weeds (Wilhelm et al., 1961; Wilhelm and Paulus, 1980; Wilhelm and Storkan, 1990; Wilhelm and Westerlund, 1994).

Methyl bromide (both natural and manmade) contributes to the depletion of the ozone layer in the stratosphere (Watson et al., 1992). In accord with the Montreal Protocol, the import and manufacture of MB in the U.S. and other developed countries will be banned by 2005 , after stepwise reductions in 1999 , 2001, and 2003 (USEPA, 1993; UNEP, 1997). The loss of MB as a soil fumigant will greatly impact the strawberry industry. Modern high yielding varieties were selected in fumigated soils for fruit quality, transport, and time of production characteristics rather than for disease resistance (Wilhelm and Paulus, 1980). All of the current California strawberry cultivars are highly susceptible to verticillium wilt (Shaw et al., 1996).

The available chemical alternatives to MB are CP, 1,3-dichloropropene (1,3-D), and metam sodium (sodium methyldithiocarbamate). None of these fumigants alone controls soilborne pathogens and weeds to the same degree as MB:CP mixtures. Metam sodium, a methyl isothiocyanate (MITC) generator, has activity against weeds, nematodes, and some fungi (Baines et al., 1957; Csinos et al., 1997; Jaworski et al., 1978; Johnson et al., 1979; McCarter et al., 1976). For the past few years, metam sodium was ranked first among the most heavily used fumigants in California (California EPA, 2001). Chloropicrin has a high activity against insects and fungi, but has less activity against nematodes and weeds than MB (Johnson and Feldmesser, 1987; Johnson et al., 1979; Wilhelm and Paulus, 1980). The fumigant 1,3-D has a high activity against nematodes and some soil arthropods, but a low to fair activity against fungi and weeds (Noling and Becker, 1994). Until 1990, 1,3-D was the most commonly applied soil fumigant in California at an annual rate of more than 7 million $\mathrm{kg}$ (McKenry, 1999). The fumigant 1,3-D, singly (Telone II) or in combination with chloropicrin (Telone C17 and Telone C35), has been used as a preplant soil treatment to protect a variety of high value vegetable crops and for replanting fruit and citrus trees (Lembright, 1990; Locascio et al., 1997).

Methyl bromide is typically applied to soil by injection through hollow shanks that are pulled through the soil either at shallow depths ( 20 to $30 \mathrm{~cm}$ ) followed by plastic mulch film application, or at deep depths $(>45 \mathrm{~cm})$ followed by surface soil compaction. Methyl bromide has an extremely low boiling point $\left(4{ }^{\circ} \mathrm{C}\right)$ and high vapor pressure $(1420 \mathrm{~mm} \mathrm{Hg}$ at $20{ }^{\circ} \mathrm{C}$ ) that plays a predominant role in its penetration throughout the soil profile and in controlling soilborne pathogens and pests.

Although alternative soil fumigants such as CP or mixtures of 1,3-D and CP can be applied by shank injection (Locascio et al., 1997), their volatilization and distribution in soil may be limited by their lower vapor pressure and higher boiling point compared to $\mathrm{MB}$ (EXTOXNET-CP, 2001; EXTOXNET-MB 2001; Lakes Environmental Software, 2000). The registered alternative fumigants (metam sodium, chloropicrin, and 1,3-D) have much higher boiling points $\left(105\right.$ to $\left.118^{\circ} \mathrm{C}\right)$ and lower vapor pressure (21 to $34 \mathrm{~mm} \mathrm{Hg}$ at $20{ }^{\circ} \mathrm{C}$ ) than MB. Therefore, the efficacy of alternative fumigants to control soil pathogens and weeds is influenced largely by the delivery method, soil type and conditions, and meteorological conditions (Ajwa et al., 2002; Ben-Yephet and Frank, 1985; Lembright, 1990; McGovern et al., 1998). For example, metam sodium applied by shank injection was found to move only a short distance from the points of injection, resulting in inadequate lateral and downward distribution for effective pathogen control (Smelt et al., 1974). Applications of metam sodium generally have been more effective 
when applied with a large quantity of water (Baines et al., 1957; Noling and Becker, 1994; Roberts et al., 1988; Smelt et al., 1974).

Raised beds covered with plastic mulch and drip irrigation systems are used in strawberry culture by most growers in California (Kasperbauer, 2000; McNiesh et al., 1985). Strawberry beds are irrigated with one or two drip tapes (collapsible, thin-wall polyethylene tubing) placed a few centimeters below the soil surface (Trout and Ajwa, 1999). Growers use drip tapes with low $\left(0.7 \mathrm{~L} \cdot \mathrm{h}^{-1}\right)$ or high $\left(1.6 \mathrm{~L} \cdot \mathrm{h}^{-1}\right)$ flow emitters spaced 20 or $30 \mathrm{~cm}$ apart. Emulsified formulations of alternative fumigants, singly or in combination, can be applied at preplant with irrigation water through these irrigation systems (Ajwa et al., 2002). An advantage of drip fumigation is that a more uniform distribution of chemicals can be achieved by spreading them in the liquid phase (Ajwa et al., 2002; Gan et al., 1998). Application of soluble formulations through drip irrigation systems may be economical and more environmentally-friendly, reduce worker exposure, and may reduce the amount of chemicals required. However, the amount of irrigation water used to deliver the fumigant, soil hydraulic properties, and fumigant application rate determine the success of drip-applied fumigants in controlling soil pathogens and weeds (Ajwa et. al, 2002).

The objectives of this study were to 1) evaluate strawberry growth and yield, disease pressure, and weed control in response to preplant application of metam sodium (Vapam HL formulation), InLine, and CP EC through drip irrigation systems; and 2) determine the optimum amount of irrigation water needed for drip fumigation of raised soil beds. Variables evaluated were fumigant application rate (maximum label rate and $60 \%$ of that rate), application of combination of fumigants, and amount of water used to apply the fumigants $\left(26,43\right.$, and $\left.61 \mathrm{~L} \cdot \mathrm{m}^{-2}\right)$. Strawberry yields from drip applied treatments were compared to yields from standard MB:CP and Telone C35 shank injection treatments and nonfumigated plots.

\section{Materials and Methods}

Site description and field preparation. The research was conducted in two major commercial strawberry production areas in California (Watsonville and Salinas) for three consecutive growing seasons between September 1997 and August 2000; nearly one-half of California strawberry production is located in the central coastal area, around Watsonville and Salinas (California Strawberry Commission, 2003). The soil in both locations had not been fumigated for more than 15 years prior to these studies. The soil in Salinas was classified as Chualar loam (Fine-loamy, mixed, thermic, Typic Argixerolls) with a pH of 6.5 and organic matter content of $0.7 \%$. The soil in Watsonville was classified as an Elder sandy loam(Coarse-loamy, mixed, thermic, Cumulic Haploxerolls) with a $\mathrm{pH}$ of 6.1 and organic matter content of $0.6 \%$. The nonfumigated soil in Watsonville was heavily infested with Verticillium dahliae Kleb. and Pythium spp., but weed pressure was medium to low. The pathogen infestation in Salinas was medium (mainly black root rot pathogens such as Pythium ultimum and binucleate Rhizoctonia spp.), but weed pressure was very high. In both locations, phytoparasitic nematodes were not detected in the soil.

At both locations, the soil was cultivated and beds ( $76 \mathrm{~cm}$ wide, $132 \mathrm{~cm}$ center to center, $30 \mathrm{~cm}$ high) were formed every year following commercial cultural practices. Slow release fertilizer $(27 \mathrm{~N}-10 \mathrm{P}-12 \mathrm{~K})$ was band applied to beds at $400 \mathrm{~kg} \cdot \mathrm{ha}^{-1}$, and the drip irrigation system was installed and tested. At the time of fumigant application, the average daily soil temperature within the raised soil bed ranged between 16 and $19{ }^{\circ} \mathrm{C}$ in Watsonville and between 18 and $20^{\circ} \mathrm{C}$ in Salinas. The 3-year average gravimetric soil water percentage (determined before fumigation) within $30 \mathrm{~cm}$ depth was $12 \% \pm 2 \%$ in Watsonville and $10 \%$ $\pm 2 \%$ in Salinas.

Fumigant and treatment description. The fumigants used in this study were commercial grade formulations. Metam sodium (Vapam HL formulation, $42 \%$ sodium methyldithiocarbamate) was provided by AMVAC (Newport Beach, Calif.). Chloropicrin (trichloronitromethane) (CP, 99\%) and an emulsified concentrate (EC) formulation $(\mathrm{CP}, 96 \%)$ were provided by Niklor Chemical Co. (Long Beach, Calif.). Telone C35, a mixture of 1,3-D and CP $(61 \%$ 1,3-D and $35 \% \mathrm{CP})$ and an emulsified formulation of Telone C35 (InLine, 58\% 1,3-D and $33 \% \mathrm{CP}$ ) were provided by Dow AgroSciences (Redeck, N.C.). Methyl bromide-CP $(67 \% \mathrm{MB}: 33 \% \mathrm{CP})$ formulation was provided by Tri-Cal Inc. (Hollister, Calif.).

Fumigant treatments (Table 1) were applied to the same beds each year within the last week of September or the first week of October, at least 4 weeks before planting. Fewer treatments were possible in Watsonville than in Salinas due to limited space. In addition to the untreated control, 12 treatments in Watsonville and 16 treatments in Salinas were randomized in a complete-block design with four replications in Watsonville (10-m-long beds) and six replications in Salinas (33 m long beds). At both locations, MB:CP (67:33) at 365 to $425 \mathrm{~kg} \cdot \mathrm{ha}^{-1}$ and Telone C35 at 453 $\mathrm{kg} \cdot \mathrm{ha}^{-1}\left(374 \mathrm{~L} \cdot \mathrm{ha}^{-1}\right)$ were shank injected at 25 to $30 \mathrm{~cm}$ depth with two chisels spaced 35 $\mathrm{cm}$ apart into soil beds that were immediately covered with green, embossed polyethylene mulch (0.03 mm thickness).

Vapam HL, InLine, and CP EC were applied into soil beds covered with polyethylene mulch through two drip tapes (Netafim Streamline 60, Netafim, Fresno, Calif.), with emitters spaced $30 \mathrm{~cm}$ apart and emitter flow

Table 1. Fumigant application rate and method.

\begin{tabular}{|c|c|c|c|c|}
\hline Treatment $^{2}$ & $\begin{array}{l}\text { Rate }^{y} \\
\left(\mathrm{~L}^{-} \mathrm{ha}^{-1}\right)\end{array}$ & Method & $\begin{array}{l}\text { Irrigation } \\
\text { water } \\
\left(\mathrm{L} \cdot \mathrm{m}^{-2}\right)\end{array}$ & Concn in water $\left(\mathrm{mg} \cdot \mathrm{L}^{-1}\right)$ \\
\hline 1) MB:CP (67:33) & $365-425 \mathrm{~kg} \cdot \mathrm{ha}^{-1}$ & Shank & -- & --- \\
\hline 2) Telone C35 & $374 \mathrm{~kg} \cdot \mathrm{ha}^{-1}$ & Shank & -- & --- \\
\hline 4) InLine & 393 & Drip & 43 & $641 \mathrm{mg} 1,3-\mathrm{D}$ and $365 \mathrm{mg} \mathrm{CP}$ \\
\hline 5) InLine & 393 & Drip & 61 & $452 \mathrm{mg} 1,3-\mathrm{D}$ and $257 \mathrm{mg} \mathrm{CP}$ \\
\hline 6) InLine & 236 & Drip & 43 & $385 \mathrm{mg} 1,3-\mathrm{D}$ and $219 \mathrm{mg} \mathrm{CP}$ \\
\hline 9) InLine+Vapam & $236+420$ & Drip & 43 & Combination $^{x}$ \\
\hline 10) InLine+Vapam & $393+700$ & Drip & 61 & Combination $^{x}$ \\
\hline 11) Vapam & 700 & Drip & 43 & $772 \mathrm{mg}$ metam sodium \\
\hline 12) Vapam & 700 & Drip & 61 & $570 \mathrm{mg}$ metam sodium \\
\hline 13) Vapam & 420 & Drip & 43 & $408 \mathrm{mg}$ metam sodium \\
\hline 14) Vapam & 700 & Drip & 26 & $1357 \mathrm{mg}$ metam sodium \\
\hline 15) CP EC+Vapam & $130+420$ & Drip & 43 & Combination $^{y}$ \\
\hline
\end{tabular}

${ }^{2} \mathrm{MB}: \mathrm{CP}(67: 33)$ was injected at 425 and $365 \mathrm{~kg} \cdot \mathrm{ha}-1$ in Watsonville and Salinas, respectively. InLine (60\% 1,3-D and 32\% CP) was drip applied at equivalent rate to shank injected Telone C35 (62\% 1,3-D and 30\% CP). Vapam HL formulation contained $42 \%$ metam sodium. Chloropicrin EC (treatment 16) was applied at 130 and $200 \mathrm{~L} \cdot \mathrm{ha}^{-1}$ in year 1 and year 2, respectively. Except for treatment 7, all drip treatments were applied through two drip tubes per bed.

${ }^{y}$ Chemical rate and volume of irrigation water are presented per bed treated area (58\% of total land area).

xTreatment 9 is a combination of treatments 6 and 13, treatment 10 is a combination of treatments 5 and 12 , and treatment 15 is a combination of treatments 13 and 16 . The combination treatments were applied simultaneously in year 1 and year 2, but sequentially in year 3 when Vapam HL was applied $6 \mathrm{~d}$ after InLine or CP EC. 
rate of $0.87 \mathrm{~L} \cdot \mathrm{h}^{-1}$ at $69 \mathrm{kPa}$. The drip tapes were placed $8 \mathrm{~cm}$ (in Watsonville) or $13 \mathrm{~cm}$ (in Salinas) from the bed center and buried at a soil depth ranging from 2 to $5 \mathrm{~cm}$. Variables evaluated (Table 1) were application rate (labeled commercial rate and $60 \%$ of that rate), application of combination of fumigants, and amount of water used to apply the fumigants $\left(26,43\right.$, and $61 \mathrm{~L} \cdot \mathrm{m}^{-2}$ of bed area). In year 1 (1997-98 growing season) and year 2 (1998-99 growing season), the combination treatments (InLine plus metam sodium or CP plus metam sodium) were injected simultaneously into the irrigation system. In year 3 (1999-2000 grow- ing season), InLine and CP EC were applied in $43 \mathrm{~L} \cdot \mathrm{m}^{-2}$ of irrigation water, but Vapam HL was applied $6 \mathrm{~d}$ later in an additional $43 \mathrm{~L} \cdot \mathrm{m}^{-2}$ of water. Fumigants were injected throughout the water application period into the drip irrigation system from either a nitrogen-pressurized cylinder containing the fumigant or with a positive
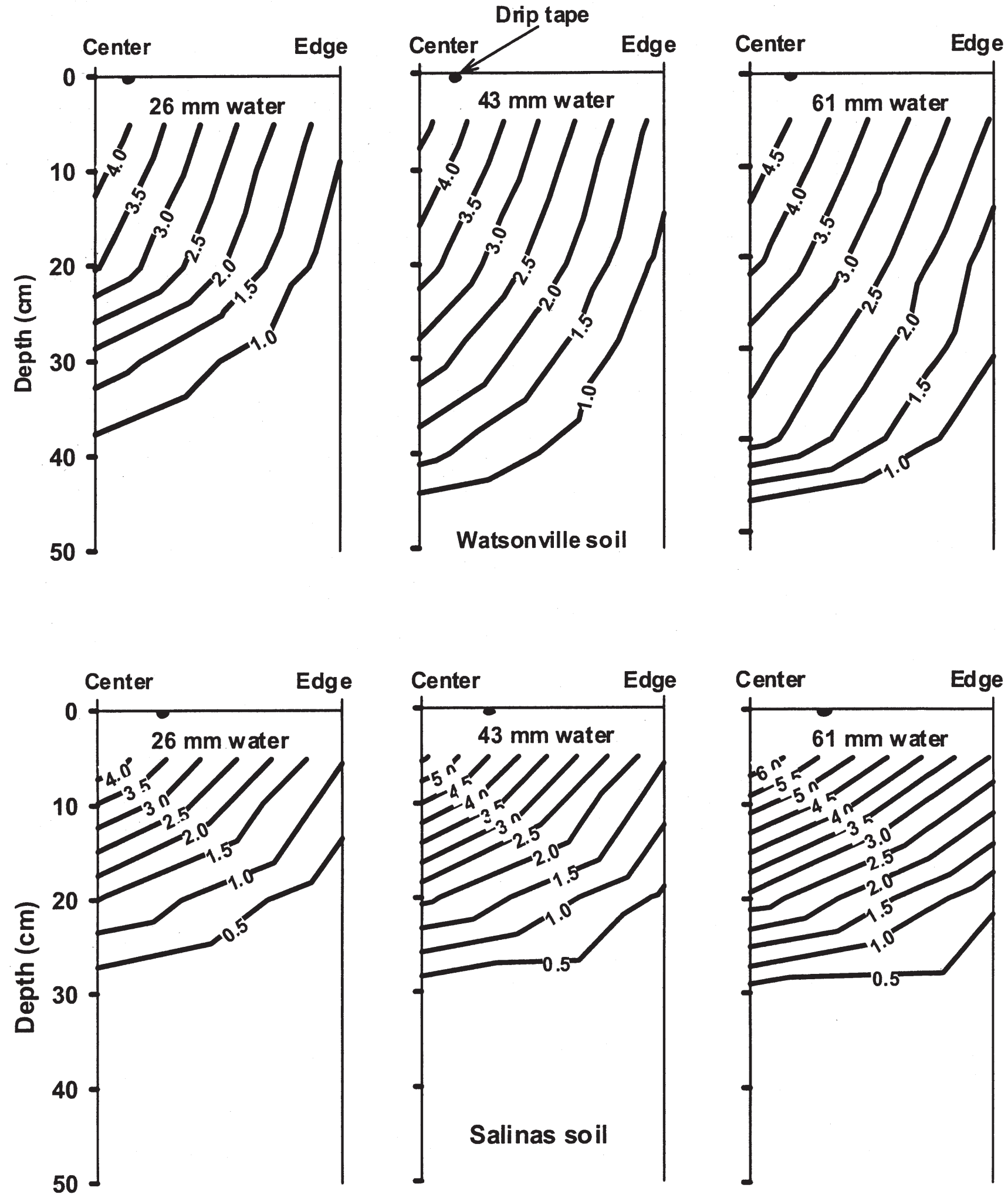

Fig. 1. The concentration of 1,3-dichloropropene ( $\mathrm{mg} \cdot \mathrm{L}^{-1}$ air) in the gaseous phase of the Watsonville sandy loam soil (top) and the Salinas loam soil (Bottom) $24 \mathrm{~h}$ after application of InLine at $393 \mathrm{~L} \cdot \mathrm{ha}^{-1}(58 \%$ 1,3-D) through the drip irrigation systems. The concentration of 1,3-D in 26, 43, and 61 mm of irrigation water were 1060, 641, and $452 \mathrm{mg} \cdot \mathrm{L}^{-1}$ water, respectively. Data are pooled across years 1 and 2. 

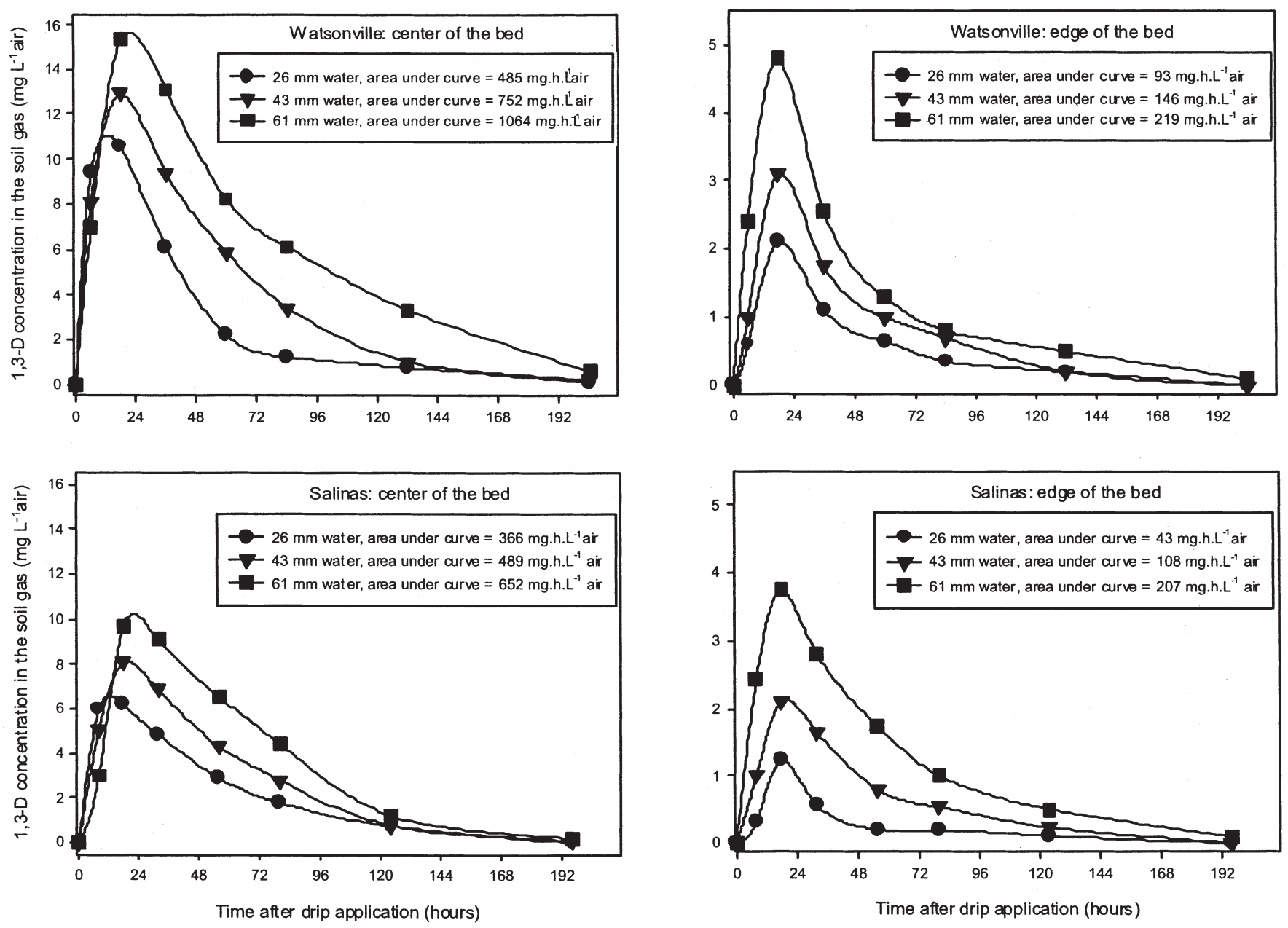

Fig. 2. Total 1,3-dichloropropene concentrations ( $\mathrm{mg} \cdot \mathrm{L}^{-1}$ air) in the center and at the edge of the Watsonville sandy loam soil (Top) and the Salinas loam soil (Bottom) over $196 \mathrm{~h}$ after drip application of InLine at $393 \mathrm{~L} \cdot \mathrm{ha}^{-1}$. Concentrations are pooled across years 1 and 2 . Treatments were not statistically different for any sampling date within each year.

displacement pump equipped with metering valves as described in detail by Ajwa et al. (2002). Water meters were used to determine the actual amount of water applied.

Fumigantconcentration in the soilprofile. To evaluate the effect of application water volume on the distribution of fumigants in soil, 1,3-D and CP concentrations were measured in the InLine treatments 3, 4, and 5 (393 $\mathrm{L} \cdot \mathrm{ha}^{-2}$ applied in 26, 43, and $\left.61 \mathrm{~L} \cdot \mathrm{m}^{-2}\right)$. Monitoring was conducted in years 1 and 2 for one-half of the raised beds following procedures described by Ajwa et al. (2002). In brief, stainless steel soil-air sampling probes $(1.0 \mathrm{~mm}$ i.d.) were placed $2 \mathrm{~cm}$ apart at the various depths $(0,5,15,30,45$, and $60 \mathrm{~cm})$ from the soil surface in the center and at the edge (30 $\mathrm{cm}$ from the center) of the raised soil bed. Soil-air sampling started immediately following the end of each application and continued for $8 \mathrm{~d}$. Soil-air 1,3-D and CP samples were taken by passing $50 \mathrm{~mL}$ of air through XAD-4 resin cartriges (Sigma-Aldrich, Milwaukee, Wis.) using a $50-\mathrm{mL}$ air-tight syringe. The trapped fumigants were extracted from the cartridges with hexane and analyzed using an Agilent (Wilmington, Del.) 6890 series gas chromatograph (GC) system equipped with an Agilent $5973 \mathrm{~N}$ mass selective detector (MS) and a Zebron ZB-624 column (30-m $\times 0.25 \mathrm{~mm}$ i.d. $\times 1.4$ (m film thickness).
Plant vigor and fruit yield. At least four weeks after fumigation, plant holes were cut in the plastic mulch at a $30-\mathrm{cm}$ spacing and strawberry (Fragaria xananassa Duchesne) cultivar 'Selva' was planted. When this research was initiated, 'Selva' was the dominant day neutral cultivar in California (personal communication, Frank Westerlund, California Strawberry Commission, Watsonville, California). Before planting, $25 \mathrm{~L} \cdot \mathrm{m}^{-2}$ of water were applied through the drip irrigation systems to wash away any residual fumigants or breakdown products that could be present in the planting zone. After transplanting, overhead sprinklers were used for a few weeks before initiating drip irrigation. Fruit was harvested at least once every week (twice per week in Salinas) throughout the production season (early April to September) and graded into marketable (fresh market grade) and nonmarketable (culls) fruits. Plant diameter was determined for the center 40 living plants in each bed by taking two measurements (north-south and east-west) of the above ground foliage from each plant about 5 months after planting and before overlapping of foliage. Fruit size was estimated by weighing 20 randomly selected marketable fruits. The percentage of diseased plants (wilting and dead) was recorded from all plants in the bed five and eight months after planting. Diseased plants were randomly selected and the surrounding soil was sampled to identify the dominant plant pathogens. Soil and plant tissue samples were assayed for Verticillium dahliae Kleb. as described by Nicot and Rouse (1987), and for Pythium spp. as described by Martin (1992). Weed control by the various treatments was assessed in February and April of years 2 and 3 . Weeds were uprooted and shaken to remove residual soil from the roots, and weighed to measure fresh weed biomass.

Statistical analysis. The general linear model (GLM) procedure and Fisher least significant difference (LSD) at $P=0.05$ tests were performed using the Statistical Analysis System (SAS) program (SAS Institute, Cary, N.C.) to determine significant differences among treatments for strawberry marketable and total yields, plant diameter, disease incidence, and weed biomass. Statistical analyses were performed on the original data without transformation. SAS was also used to determine the existence of a significant relationship between average fruit weight and marketable yield.

\section{Results}

Distribution of 1,3-D and $C P$ in the soil profile. The distribution patterns of 1,3-D (cis plus trans isomers) in one half of the bed 
profile of the Watsonville and Salinas soils $18 \mathrm{~h}$ after applying one rate of InLine (393 $\left.\mathrm{L} \cdot \mathrm{ha}^{-1}\right)$ in three different amounts of irrigation water are presented in Fig. 1. These results are averages of 2-year concentrations. In general, maximum 1,3-D concentrations were detected between 12 and $24 \mathrm{~h}$ after drip fumigation and only minute amounts $\left(<0.2 \mathrm{mg} \cdot \mathrm{L}^{-1}\right.$ air $)$ were detected after $8 \mathrm{~d}$. The $\mathrm{CP}$ distribution patterns (data not shown) were similar to the 1,3-D patterns and CP concentrations were 40 to $55 \%$ of $1,3-\mathrm{D}$ concentrations during the initial $36 \mathrm{~h}$. However, CP concentrations in the soil decreased at faster rates than 1,3-D concentrations, and the average half-life of $\mathrm{CP}$ was much shorter (1 to $2 \mathrm{~d}$ ) than the half-life of 1,3-D (3d).

At both sites, the concentration of 1,3-D (cis and trans isomers) in the soil air space increased with increasing amounts of application water, even though the concentration of 1,3-D decreased with increasing the water volume. Fumigants in the Watsonville soil moved more vertically and less horizontally than in Salinas soil due to higher sand content and closer spacing between the two drip tapes (Fig. 1). In Watsonville, the drip tapes were placed close to the center of the bed (one-fifth the distance to the bed edge), which resulted in large concentration differences between the middle and the edge of the bed. To better compare the efficacy of various treatments, total fumigant concentrations in the soil airspace to $60 \mathrm{~cm}$ depth in the center and at the edge of the soil bed were calculated, and the dose $\left(\sum\right.$ concentration $\times$ time $)$ for one-half of the soil bed was estimated from the area under the curve as shown in Fig. 2. In Watsonville, the average dose values for one-half of the soil bed were 278,449 , and $642 \mathrm{mg} \cdot \mathrm{h} \cdot \mathrm{L}^{-1}$ for 1,3-D and 101, 168, and $249 \mathrm{mg} \cdot \mathrm{h} \cdot \mathrm{L}^{-1}$ for $\mathrm{CP}$ EC in the 26,43 , and $61 \mathrm{~L} \cdot \mathrm{m}^{-2}$ water treatments, respectively. In Salinas, the average dose values for one-half of the soil bed were 205, 299, and $367 \mathrm{mg} \cdot \mathrm{h} \cdot \mathrm{L}^{-1}$ for $1,3-\mathrm{D}$ and 83 , 111 , and $152 \mathrm{mg} \cdot \mathrm{h} \cdot \mathrm{L}^{-1}$ for CP EC in the 26,43 , and $61 \mathrm{~L} \cdot \mathrm{m}^{-2}$ water treatments, respectively. Although the area under the curves (Fig. 2) differed widely among the water treatments, these differences were not statistically different $(P<0.05)$ due to the large variability among replicate measurements within each year, and error bars were not included for clarity.

Disease control. In Watsonville, the most important pathogen was Verticillium dahliae ( $\approx 30$ viable microsclerotia/g soil), although general root rot pathogens such as Pythium spp. and binucleate Rhizoctonia spp. were present as well. However, the percentage of dead strawberry plants varied among the growth stages and among the years (Table 2). In year 1, the percentage of dead plants in Watsonville during early growth stages (November through March) was similar $(<5 \%)$ among all treatments, but plant mortality increased tremendously during peak production (8 months after planting), especially in the untreated control $(35 \%)$, the combination treatments (25\% to $30 \%)$, and Vapam treatments (15\% to $16 \%$ ). In year 2 , the percentage of dead plants at the 5-month growth stage in the untreated control was significantly greater than any fumigant treatment.

Table 2. Percentage of dead strawberry plants in the various treatments in Watsonville 5 and 8 months after planting.

\begin{tabular}{|c|c|c|c|c|c|c|c|c|}
\hline \multirow{2}{*}{ Treatment } & \multirow{2}{*}{$\begin{array}{c}\text { Rate } \\
\left(\mathrm{L} \cdot \mathrm{ha}^{-1}\right)\end{array}$} & \multirow{2}{*}{$\begin{array}{c}\text { Irrigation } \\
\text { water } \\
\left(\mathrm{L} \cdot \mathrm{m}^{-2}\right)\end{array}$} & \multicolumn{6}{|c|}{ Dead plants $(\%)$} \\
\hline & & & \multicolumn{2}{|c|}{ Year 1} & \multicolumn{2}{|c|}{ Year 2} & \multicolumn{2}{|c|}{ Year 3} \\
\hline 1) $\mathrm{MB}: \mathrm{CP}$ & $425^{z}$ & 0 & 2 & $4 \mathrm{e}^{\mathrm{y}}$ & $2 c$ & $3 d$ & $1 \mathrm{~b}$ & $4 \mathrm{bc}$ \\
\hline 3) InLine & 393 & 26 & 2 & $8 \mathrm{de}$ & $3 \mathrm{c}$ & $4 \mathrm{~cd}$ & $1 \mathrm{~b}$ & $4 \mathrm{bc}$ \\
\hline 4) InLine & 393 & 43 & 2 & $7 \mathrm{e}$ & $3 \mathrm{c}$ & $3 \mathrm{~d}$ & $1 \mathrm{~b}$ & $3 \mathrm{bc}$ \\
\hline 5) InLine & 393 & 61 & 2 & $4 \mathrm{e}$ & $3 \mathrm{c}$ & $3 \mathrm{~d}$ & $1 \mathrm{~b}$ & $1 \mathrm{c}$ \\
\hline 6) InLine & 236 & 43 & 2 & $9 \mathrm{de}$ & $12 \mathrm{~b}$ & $20 \mathrm{a}$ & $1 \mathrm{~b}$ & $4 \mathrm{bc}$ \\
\hline 12) Vapam & 700 & 61 & 3 & $15 \mathrm{~cd}$ & $6 \mathrm{bc}$ & $7 \mathrm{bcd}$ & $2 \mathrm{~b}$ & $6 a b$ \\
\hline 13) Vapam & 420 & 43 & 3 & $16 \mathrm{c}$ & $8 \mathrm{bc}$ & $11 \mathrm{bc}$ & $4 \mathrm{ab}$ & $7 \mathrm{ab}$ \\
\hline 15) CP EC+Vapam & $130+420$ & 43 & 3 & $30 \mathrm{ab}$ & $7 \mathrm{bc}$ & $13 \mathrm{~b}$ & $1 \mathrm{~b}$ & $1 \mathrm{c}$ \\
\hline 16) $\mathrm{CP}^{\mathrm{E}} \mathrm{C}^{\mathrm{x}}$ & $130 / 200$ & 43 & --- & --- & $8 \mathrm{bc}$ & $13 \mathrm{~b}$ & $1 \mathrm{~b}$ & $4 \mathrm{bc}$ \\
\hline 17) Untreated & 0 & --- & 5 & $35 \mathrm{a}$ & $22 \mathrm{a}$ & $24 \mathrm{a}$ & $6 \mathrm{a}$ & $10 \mathrm{a}$ \\
\hline
\end{tabular}

${ }^{2}$ Units are in $\mathrm{kg} \cdot \mathrm{ha}^{-1}$.

${ }^{y}$ Percentages followed by the same letter in each column are not significantly different at $P<0.05$.

${ }^{x}$ Chloropicrin EC (Treatment 16) was not applied in 1998. Chloropicrin EC was applied at $130 \mathrm{~L}^{\circ} \mathrm{ha}^{-1}$ in year 2 and at $200 \mathrm{~L} \cdot \mathrm{ha}{ }^{-1}$ in year 3.

Table 3. Average diameter of strawberry plants in the various fumigation treatments relative to MB:CP (67:33) 5 months after planting.

\begin{tabular}{|c|c|c|c|c|c|c|c|c|}
\hline \multirow[b]{3}{*}{ Treatment ${ }^{2}$} & \multirow{3}{*}{$\begin{array}{c}\text { Rate } \\
\left(\mathrm{L} \cdot \mathrm{ha}^{-1}\right)\end{array}$} & \multirow{3}{*}{$\begin{array}{c}\text { Irrigation } \\
\text { water } \\
\left(\mathrm{L} \cdot \mathrm{m}^{-2}\right)\end{array}$} & \multicolumn{6}{|c|}{ Avg diam (\%) } \\
\hline & & & \multicolumn{3}{|c|}{ Watsonville } & \multicolumn{3}{|c|}{ Salinas } \\
\hline & & & Year 1 & Year 2 & Year 3 & Year 1 & Year 2 & Year3 \\
\hline 1) $\mathrm{MB}: \mathrm{CP}$ & $425^{y}$ & --- & $100 a^{x}$ & $100 \mathrm{a}$ & $100 \mathrm{a}-\mathrm{e}$ & $100 \mathrm{bc}$ & $100 \mathrm{bc}$ & $100 \mathrm{a}$ \\
\hline 3) InLine & 393 & 26 & $101 \mathrm{a}$ & $97 \mathrm{ab}$ & $101 \mathrm{abc}$ & $97 \mathrm{de}$ & $106 \mathrm{ab}$ & $101 \mathrm{a}$ \\
\hline 4) InLine & 393 & 43 & $102 \mathrm{a}$ & $93 a b c$ & $91 \mathrm{~b}-\mathrm{e}$ & $101 \mathrm{a}-\mathrm{e}$ & $101 a b c$ & $102 \mathrm{a}$ \\
\hline 5) InLine & 393 & 61 & $105 \mathrm{a}$ & $92 a b c$ & $110 \mathrm{a}$ & $101 \mathrm{a}-\mathrm{e}$ & $112 \mathrm{a}$ & $103 \mathrm{a}$ \\
\hline 6) InLine & 236 & 43 & $96 \mathrm{ab}$ & $87 \mathrm{~cd}$ & $85 \mathrm{e}$ & $101 \mathrm{a}-\mathrm{e}$ & $107 \mathrm{ab}$ & $102 \mathrm{a}$ \\
\hline 9) InLine+Vapam & $236+420$ & 43 & $96 \mathrm{ab}$ & 88 bcd & $104 a b$ & $102 \mathrm{a}-\mathrm{e}$ & $106 a b$ & $103 \mathrm{a}$ \\
\hline 10) InLine+Vapam & $393+700$ & 61 & --- & --- & --- & $101 \mathrm{a}-\mathrm{c}$ & $107 a b$ & $102 \mathrm{a}$ \\
\hline 11) Vapam & 700 & 43 & $92 a b c$ & $82 \mathrm{~d}$ & $96 \mathrm{~b}-\mathrm{e}$ & $98 \mathrm{~b}-\mathrm{d}$ & $99 \mathrm{bc}$ & $97 \mathrm{a}$ \\
\hline 12) Vapam & 700 & 61 & $97 \mathrm{ab}$ & $93 a b c$ & $85 \mathrm{e}$ & $100 \mathrm{a}-\mathrm{e}$ & $102 a b c$ & $99 \mathrm{a}$ \\
\hline 13) Vapam & 420 & 43 & $90 a b c$ & 89 bcd & 89 cde & $98 \mathrm{~b}-\mathrm{d}$ & $102 a b c$ & 99 a \\
\hline 14) Vapam & 700 & 26 & --- & --- & --- & 100 a-e & $106 \mathrm{ab}$ & $101 \mathrm{a}$ \\
\hline
\end{tabular}

${ }^{2}$ Average plant diameter values from the MB:CP treatment in year 1, year 2, and year 3 were 27.3, 24.0, and 20.3 cm, repectively, in Watsonville, and 28.2, 21.8 , and $23.8 \mathrm{~cm}$ in Salinas.

${ }^{\mathrm{y} U n i t s}$ are $\mathrm{kg} \cdot \mathrm{ha}^{-1}$.

${ }^{x}$ Percentages followed by the same letter in each column are not significantly different at $P<0.05$ (statistical analysis was performed using the actual plant diameter data).

${ }^{\text {w}}$ Chloropicrin EC (Treatment 16) was not applied in Year 1. Chloropicrin EC was applied at $130 \mathrm{~L} \cdot \mathrm{ha}^{-1}$ in year 2 and at $200 \mathrm{~L} \cdot \mathrm{ha}^{-1}$ in year 3. 
Most of the wilt occurred during early growth stages, and the increase in the percentage of dead plants between the early (5-month) and late (8-month) growth stages was not as large as during the year 1 growing season. In year 3 , verticillium wilt was not as severe as in the previous growing seasons and the percentage of dead plants in the untreated control did not exceed $10 \%$.

In Salinas, the predominant pathogens were the general root rot Pythium spp. (20 to 50 propagules/g soil) and lethal pathogens such as Verticillium dahliae or Phytophthora spp. were not present in the soil. The number of visibly diseased plants throughout the growing season in Salinas was small $(<2 \%)$ in any of the treatments (data not shown), and the percentage of dead plants was not significantly different $(P<$ 0.05) among all chemical treatments.

Plant vigor and fruit yield. Plant diameter measurements were taken within five months after planting. Accurate measurements during late growth stages were not possible due to foliage overlapping. Above ground foliage diameter of five month-old strawberry plants growing in the various treatments relative to $\mathrm{MB}: \mathrm{CP}$ fumigation is presented in Table 3. In Salinas, plant diameter in any chemical treatment was similar to that grown in the MB:CP treatment. Only plants grown in the untreated control plots exhibited significant reduction in foliage growth. In Watsonville, plant diameter measurements at 5 months varied among treatments and growing seasons and, in general, were less than those in $\mathrm{MB}: \mathrm{CP}$ treatment. After five months, however, plants growing in high rates of drip applied $\mathrm{CP}$ EC and InLine at both sites developed at a faster rate and had more vegetative growth than plants growing in the MB:CP treatment.

Marketable and total fruit yields for the 3 years in Watsonville and Salinas plots are presented in Tables 4 and 5, respectively. Average weight of 20 marketable fruit (data not shown) followed the same treatment effect on yields and was strongly correlated $(r=0.95, P$ $<0.001$ ) with marketable yield, indicating that greater yield was mainly due to larger fruit size rather than the numbers of fruit produced. At the Watsonville site, yields from the untreated control were less than one-half the yields from the MB:CP plots, and in general, yields were considerably greater in the chemical treatments than in the untreated plots. Although verticillium wilt did not occur at the Salinas site and the soil had medium disease pressure with black root rot pathogens, yields from the untreated control were considerably less than the yields from the MB:CP plots. Bed shank injection with Telone $\mathrm{C} 35$ at $374 \mathrm{~L} \cdot \mathrm{ha}^{-1}$ generally produced yields comparable $(99 \% \pm 6 \%)$ to those produced by shank fumigation with MB:CP. The main exception was in the Telone C35 plots at the Watsonville site in year 3 and at the Salinas site in year 1 where yields were considerably less (80\% to $93 \%$ ) than yields from the MB:CP treatment.

Table 4. Marketable and total fruit yields of strawberry from Watsonville plots as influenced by the various fumigation treatments relative to MB:CP (67:33) shank injection. ${ }^{2}$

\begin{tabular}{|c|c|c|c|c|c|c|c|c|}
\hline \multirow{2}{*}{ Treatment } & \multirow{2}{*}{$\begin{array}{c}\text { Rate } \\
\left(\mathrm{L} \cdot \mathrm{ha}^{-1}\right)\end{array}$} & \multirow{2}{*}{$\begin{array}{c}\text { Irrigation } \\
\text { water } \\
\left(\mathrm{L} \cdot \mathrm{m}^{-2}\right)\end{array}$} & \multicolumn{6}{|c|}{ Yield (\%) } \\
\hline & & & \multicolumn{2}{|c|}{ Year 1} & \multicolumn{2}{|c|}{ Year 2} & \multicolumn{2}{|c|}{ Year 3} \\
\hline 1) $\mathrm{MB}: \mathrm{CP}$ & $425^{y}$ & 0 & $100 a b^{x}$ & $100 \mathrm{ab}$ & $100 \mathrm{a}$ & $100 \mathrm{a}$ & $100 \mathrm{abc}$ & $100 \mathrm{abc}$ \\
\hline 3) InLine & 393 & 26 & $97 \mathrm{ab}$ & $97 \mathrm{ab}$ & $94 \mathrm{ab}$ & $93 \mathrm{ab}$ & $88 \mathrm{a}-\mathrm{e}$ & $88 \mathrm{a}-\mathrm{e}$ \\
\hline 4) InLine & 393 & 43 & $91 \mathrm{abc}$ & $92 \mathrm{abc}$ & $91 \mathrm{abc}$ & $91 \mathrm{ab}$ & $97 \mathrm{a}-\mathrm{d}$ & $97 \mathrm{a}-\mathrm{d}$ \\
\hline 5) InLine & 393 & 61 & $109 a$ & $110 \mathrm{a}$ & $93 \mathrm{ab}$ & $92 \mathrm{ab}$ & $110 \mathrm{ab}$ & $109 \mathrm{abc}$ \\
\hline 6) InLine & 236 & 43 & $95 \mathrm{ab}$ & $94 \mathrm{ab}$ & $68 \mathrm{~d}$ & $67 \mathrm{~d}$ & $81 \mathrm{~b}-\mathrm{e}$ & $79 \mathrm{~cd}$ \\
\hline 12) Vapam & 700 & 61 & $79 \mathrm{bcd}$ & $79 \mathrm{bcd}$ & $79 \mathrm{bcd}$ & $80 \mathrm{bcd}$ & $70 \mathrm{def}$ & $68 \mathrm{de}$ \\
\hline 13) Vapam & 420 & 43 & $67 \mathrm{de}$ & $67 \mathrm{de}$ & $72 \mathrm{~cd}$ & $72 \mathrm{~d}$ & 67 ef & $67 \mathrm{ef}$ \\
\hline 15) CP EC+Vapam & $130+420$ & 43 & $51 \mathrm{e}$ & $52 \mathrm{e}$ & $75 \mathrm{bcd}$ & $73 \mathrm{~cd}$ & $114 \mathrm{a}$ & $110 \mathrm{ab}$ \\
\hline 16) $\mathrm{CP}^{\mathrm{E}} \mathrm{C}^{\mathrm{w}}$ & $130 / 200$ & 43 & -- & -- & $69 \mathrm{~d}$ & $67 \mathrm{~d}$ & $97 \mathrm{a}-\mathrm{d}$ & $95 \mathrm{a}-\mathrm{d}$ \\
\hline 17) Untreated & 0 & --. & $49 \mathrm{e}$ & $50 \mathrm{e}$ & $34 \mathrm{e}$ & $33 \mathrm{e}$ & $45 \mathrm{f}$ & $48 \mathrm{e}^{4}$ \\
\hline
\end{tabular}

${ }^{2}$ The respective marketable and total fruit yields from the MB:CP treatment were 62500 and $84170 \mathrm{~kg} \cdot \mathrm{ha}^{-1}$ in year 1,56670 and $75000 \mathrm{~kg} \cdot \mathrm{ha}{ }^{-1}$ in year 2 , and 45610 and $62650 \mathrm{~kg} \cdot \mathrm{ha}^{-1}$ in year 3.

'Units are $\mathrm{kg} \cdot \mathrm{ha}^{-1}$.

${ }^{x}$ Percentages followed by the same letter in each column are not significantly different at $P<0.05$ (statistical analysis was performed using the actual yield data). ${ }^{\text {w}}$ Chloropicrin EC (Treatment 16) was not applied in year 1. Chloropicrin EC was applied at $130 \mathrm{~L} \cdot \mathrm{ha}^{-1}$ in year 2 and at $200 \mathrm{~L} \cdot \mathrm{ha}{ }^{-1}$ in year 3.

Table 5. Marketable and total fruit yields of strawberry from Salinas plots as influenced by the various fumigation treatments relative to MB:CP (67:33) shank injection. ${ }^{2}$

\begin{tabular}{|c|c|c|c|c|c|c|c|c|}
\hline \multirow[b]{3}{*}{ Treatment } & \multirow{3}{*}{$\begin{array}{c}\text { Rate } \\
\left(\mathrm{L} \cdot \mathrm{ha}^{-1}\right)\end{array}$} & \multirow{3}{*}{$\begin{array}{c}\text { Irrigation } \\
\text { water } \\
\left(\mathrm{L} \cdot \mathrm{m}^{-2}\right)\end{array}$} & \multicolumn{6}{|c|}{ Yield (\%) } \\
\hline & & & \multicolumn{2}{|c|}{ Year 1} & \multicolumn{2}{|c|}{ Year 2} & \multicolumn{2}{|c|}{ Year 3} \\
\hline & & & Market & Total & Market & Total & Market & Total \\
\hline 1) MB:PC & $425^{y}$ & 0 & $100 a-d^{x}$ & $100 \mathrm{abc}$ & $100 \mathrm{~b}-\mathrm{e}$ & $100 \mathrm{~d}$ & $100 \mathrm{bc}$ & 100 bed \\
\hline 2) Telone C35 & $374^{y}$ & 0 & 93 bcd & $96 \mathrm{abc}$ & $106 \mathrm{a}-\mathrm{e}$ & $101 \mathrm{~d}$ & $100 \mathrm{bc}$ & $101 \mathrm{bc}$ \\
\hline 3) InLine & 393 & 26 & $106 \mathrm{abc}$ & $99 \mathrm{abc}$ & $110 \mathrm{a}-\mathrm{d}$ & $115 \mathrm{abc}$ & $101 \mathrm{ab}$ & $101 \mathrm{bc}$ \\
\hline 4) InLine & 393 & 43 & $105 \mathrm{abc}$ & $103 \mathrm{abc}$ & $117 \mathrm{ab}$ & $108 \mathrm{a}-\mathrm{d}$ & $107 \mathrm{ab}$ & $107 \mathrm{ab}$ \\
\hline 5) InLine & 393 & 61 & $108 \mathrm{ab}$ & $103 \mathrm{abc}$ & $123 \mathrm{a}$ & $119 \mathrm{a}$ & $102 \mathrm{ab}$ & $101 \mathrm{bc}$ \\
\hline 6) InLine & 236 & 43 & $108 \mathrm{ab}$ & $107 \mathrm{ab}$ & $104 \mathrm{a}-\mathrm{c}$ & $109 \mathrm{a}-\mathrm{d}$ & $101 \mathrm{ab}$ & $101 \mathrm{bc}$ \\
\hline 7) InLine/4 lines & 236 & 43 & $107 \mathrm{ab}$ & $107 \mathrm{ab}$ & 97 cde & $106 \mathrm{bcd}$ & --- & --- \\
\hline 8) InLine/preirrig & 236 & 43 & $111 \mathrm{a}$ & $108 \mathrm{a}$ & $113 \mathrm{abc}$ & $116 \mathrm{ab}$ & --- & --- \\
\hline 9) InLine+Vapam & $236+420$ & 43 & $95 \mathrm{bcd}$ & $97 \mathrm{abc}$ & $106 \mathrm{a}-\mathrm{c}$ & $116 \mathrm{ab}$ & $103 \mathrm{ab}$ & $103 \mathrm{bc}$ \\
\hline 10) InLine+Vapam & $393+700$ & 61 & $100 \mathrm{ac}$ & $101 \mathrm{abc}$ & $89 \mathrm{e}$ & $106 \mathrm{bcd}$ & $110 \mathrm{a}$ & $112 \mathrm{a}$ \\
\hline 11) Vapam & 700 & 43 & 96 ad & $95 \mathrm{bc}$ & $101 \mathrm{~b}-\mathrm{e}$ & $106 \mathrm{bcd}$ & 99 bc & 100 bed \\
\hline 12) Vapam & 700 & 61 & $91 \mathrm{~cd}$ & $91 \mathrm{c}$ & $91 \mathrm{c}$ & $99 \mathrm{~d}$ & $78 \mathrm{c}$ & $80 \mathrm{c}$ \\
\hline 13) Vapam & 420 & 43 & $91 \mathrm{a}-\mathrm{d}$ & $91 \mathrm{abc}$ & $93 \mathrm{de}$ & $98 \mathrm{~d}$ & $80 \mathrm{e}$ & $80 \mathrm{e}$ \\
\hline 14) Vapam & 700 & 26 & $91 \mathrm{~d}$ & $93 \mathrm{bc}$ & $93 \mathrm{de}$ & $99 \mathrm{~d}$ & $85 \mathrm{de}$ & $87 \mathrm{c}$ \\
\hline 15) CP EC+ Vapam & $130+420$ & 43 & $98 \mathrm{a}-\mathrm{d}$ & $100 \mathrm{abc}$ & $93 \mathrm{de}$ & $98 \mathrm{~d}$ & $103 \mathrm{ab}$ & $106 \mathrm{ab}$ \\
\hline 16) $\mathrm{CP}$ EC & $130 / 200$ & 43 & $99 \mathrm{a}-\mathrm{d}$ & $102 \mathrm{abc}$ & $91 \mathrm{e}$ & $101 \mathrm{~d}$ & $102 \mathrm{ab}$ & $102 \mathrm{bc}$ \\
\hline 17) Untreated & 0 & --- & $93 \mathrm{bcd}$ & $93 \mathrm{c}$ & $69 \mathrm{f}$ & $74 \mathrm{e}$ & $79 \mathrm{f}$ & $80 \mathrm{e}$ \\
\hline
\end{tabular}

${ }^{2}$ The respective marketable and total fruit yields from the MB:CP treatment were 26250 and $46010 \mathrm{~kg} \cdot \mathrm{ha}^{-1}$ in year 1,17500 and $39750 \mathrm{~kg} \cdot \mathrm{ha}{ }^{-1} \mathrm{in} \mathrm{year} 2$, and 25890 and $58050 \mathrm{~kg} \cdot \mathrm{ha}^{-1}$ in year 3.

'Units are $\mathrm{kg} \cdot \mathrm{ha}^{-1}$.

${ }^{x}$ Percentages followed by the same letter in each column are not significantly different at $P<0.05$ (statistical analysis was performed using the actual yield data). 
At both sites, the highest average yield over the 3 years was in plots treated with a high rate of InLine (393 L.ha ${ }^{-1}$ ) applied with a high amount of water $\left(61 \mathrm{~L} \cdot \mathrm{m}^{-2}\right)$. The average 3-year yield in this treatment was $110 \%$ and $104 \%$ relative to the $\mathrm{MB}: \mathrm{CP}$ treatment in Watsonville and Salinas, respectively. Differences between the high rate of InLine, however, were not statistically different $(P<$ $0.05)$, regardless of the amount of application water. In Watsonville, yields from beds treated with a high rate of InLine applied in low and medium (26 and $43 \mathrm{~L} \cdot \mathrm{m}^{-2}$ ) amounts of water were equivalent or less than yields from the MB:CP treatment. Reduced application rate (60\% of the label maximum rate) of InLine produced variable yields over the three growing seasons at Watsonville. The average three year yield from the reduced application rate treatment was considerably less $(80 \%)$ than yields from MB:CP. In Salinas, however, the reduced $(60 \%)$ and full rates of InLine almost always produced yields equivalent or greater than MB:CP treatment, regardless of the amount of application water.

Yield from the Vapam HL treated beds were lower than yields from any of the fullrate InLine treatments. The market yield from the Vapam HL treatments relative to MB: $\mathrm{CP}$ treatment ranged between $67 \%$ to $86 \%$ in Watsonville and between $78 \%$ to $99 \%$ in Salinas. Yields from plots treated with low rates of InLine $\left(235 \mathrm{~L} \cdot \mathrm{ha}^{-1}\right)$ or CP EC $\left(130 \mathrm{~L} \cdot \mathrm{ha}^{-1}\right)$ applied simultaneously with Vapam HL (year 1 and year 2) were less than those in MB:CP plots. However, yields from these combination treatments applied sequentially (Vapam HL was applied $6 \mathrm{~d}$ after InLine or CP) in the year 3 produced yields comparable to or greater than yields from MB:CP treated soils.

Weed control. Weed control under the various fumigant treatments relative to the untreated control for the year 2 and year 3 growing seasons is shown in Table 6 . The dominant ( $>60 \%$ of total biomass) weeds in Watsonville were little mallow (Malva parviflora L.), burclover(Medicago polymorpha L.), and redstem filaree (Erodium circutarium [L.] L Herr. ex. Ait). The dominant ( $>50 \%)$ weeds in Salinas were burclover, little mallow, shepherd's-purse (Capsella bursa-pastoris L. Medik.), and common purslane (Portulaca oleracea L.). Total fresh weed biomass relative to untreated control (Table 6) showed that weed population was greatly reduced in all treatments. In Salinas, weed control by the InLine treatments was better than that in the MB:CP or Telone C35 shank injection treatments.

\section{Discussion}

The considerable reduction in plant growth in Watsonville (Table 3) may indicate that some of the treatments were not sufficient to control the disease pressure and/or may have caused phytotoxicity. In Salinas, however, similar plant diameter values between chemical treatments indicate that there was no phytotoxic effect by any of the fumigants or their degradation products, and that a four-week plant back time is sufficient for drip fumigation with InLine, CP EC, or Vapam HL. Also, our studies on fumigant distribution in these soils found that most of the fumigants dissipate or degrade in $14 \mathrm{~d}$ following application (Ajwa et al., 2002), and no known phytotoxic degradation products were detected after $20 \mathrm{~d}$.

The severity of the verticillium wilt in Watsonville decreased over the three seasons (Table 2 ). In year 1 , wilt symptoms became obvious in June when soil temperature was suitable for disease development by this pathogenic fungus. In year 2, most of the wilt occurred during early growth stages, possibly due to the exceptionally warm temperatures during this growth period. In year 3 , wilt symptoms were considerably less than in the previous growing seasons even though the viable number of microscerotia of Verticillium dahliae Kleb. in the untreated soil was similar among the three growing seasons.
Disease incidence (Table 2) and marketable and total fruit yields (Tables 4 and 5) in both locations indicate that treatments can be clustered into three production groups: 1) the $\mathrm{MB}: \mathrm{CP}$ and full rate of Telone $\mathrm{C} 35$ or InLine treatments produced the greatest yields; 2) metam sodium, reduced rates of CP EC or InLine, and the combination treatments (applied simultaneously) were inconsistent and produced intermediate yields; and 3) the untreated control produced the least yields. The great reduction in yield in the untreated control plots in Watsonville was due to the severe plant infestation by verticillium wilt. Although wilt at the Salinas site was not observed, the soil had significant black root rot pathogens that significantly reduced yield in the untreated control relative to the MB:CP treatment.

The inconsistent yield production from shank-injected Telone C35 treatments in Watsonville (year 3) and in Salinas (year 1) was possibly due to poor distribution uniformity of the shank-injected fumigants (Table 5). In these studies, the MB injection equipment was used to apply Telone $\mathrm{C} 35$. Because both active ingredients of Telone C35 (1,3-D and CP) have low vapor pressures and high boiling points relative to MB, they do not volatilize as quickly or diffuse as far from the injection. Therefore, reduced yield in some of the shank-injected Telone C35 may be attributed to inadequate configuration of the application equipment that resulted in poor fumigant distribution in soil.

Although not statistically different $(P<$ $0.05)$, InLine applied with the large amount (61 $\mathrm{L} \cdot \mathrm{m}^{-2}$ ) of irrigation water generally produced yields greater than MB:CP shank injection. The slight reduction in fruit yields from the same application rate of InLine in less amount of water was due to insufficient fumigant concentration at the edge of the bed. Fumigant dissipation patterns (Fig. 1) in Watsonville and Salinas found greater 1,3-D and CP concentrations and better distribution uniformity in the soil gaseous phase when InLine was applied with

Table 6. Weed control under the various fumigation treatments relative to untreated control.

\begin{tabular}{|c|c|c|c|c|c|c|}
\hline \multirow[b]{3}{*}{ Treatment $^{\mathrm{y}}$} & \multirow{3}{*}{$\begin{array}{c}\text { Rate } \\
\left(\mathrm{L} \cdot \mathrm{ha}^{-1}\right)\end{array}$} & \multirow{3}{*}{$\begin{array}{c}\text { Irrigation } \\
\text { water } \\
\left(\mathrm{L} \cdot \mathrm{m}^{-2}\right)\end{array}$} & \multicolumn{4}{|c|}{ Weed control $(\%)^{\mathrm{z}}$} \\
\hline & & & \multicolumn{2}{|c|}{ Watsonville } & \multicolumn{2}{|c|}{ Salinas } \\
\hline & & & Year 2 & Year 3 & Year 2 & Year 3 \\
\hline 1) $\mathrm{MB}: \mathrm{PC}$ & $425^{x}$ & --- & $76 b^{w}$ & $96 \mathrm{~b}$ & $78 \mathrm{~b}-\mathrm{c}$ & 73 cde \\
\hline 2) Telone C35 & $374^{x}$ & --- & $63 \mathrm{~b}$ & $70 \mathrm{ab}$ & $66 \mathrm{~b}$ & $68 \mathrm{bc}$ \\
\hline 3) InLine & 393 & 26 & $75 \mathrm{~b}$ & $96 \mathrm{~b}$ & $93 \mathrm{c}$ & $90 \mathrm{ef}$ \\
\hline 4) InLine & 393 & 43 & $71 \mathrm{~b}$ & $93 \mathrm{~b}$ & $96 \mathrm{f}$ & 87 def \\
\hline 5) InLine & 393 & 61 & $76 \mathrm{~b}$ & $98 \mathrm{~b}$ & $95 \mathrm{f}$ & 86 def \\
\hline 6) InLine & 236 & 43 & $74 \mathrm{~b}$ & $90 \mathrm{~b}$ & 92 ef & 84 def \\
\hline 7) InLine/4 lines & 236 & 43 & --- & --- & $98 \mathrm{f}$ & --- \\
\hline 8) InLine/preirrig & 236 & 43 & --- & --- & 87 def & --- \\
\hline 9) InLine+Vapam & $236+420$ & 43 & $61 \mathrm{~b}$ & $97 \mathrm{~b}$ & $83 \mathrm{~b}-\mathrm{f}$ & 84 def \\
\hline 10) InLine+Vapam & $393+700$ & 61 & --- & --- & $86 \mathrm{c}-\mathrm{f}$ & $91 \mathrm{f}$ \\
\hline 11) Vapam & 700 & 43 & $54 \mathrm{~b}$ & $97 \mathrm{~b}$ & $72 \mathrm{~cd}$ & $64 \mathrm{bc}$ \\
\hline 12) Vapam & 700 & 61 & $58 \mathrm{~b}$ & $98 \mathrm{~b}$ & $71 \mathrm{cb}$ & $65 \mathrm{bc}$ \\
\hline 13) Vapam & 420 & 43 & $55 \mathrm{~b}$ & $91 \mathrm{~b}$ & $69 \mathrm{~b}$ & $54 \mathrm{~b}$ \\
\hline 14) Vapam & 700 & 26 & --- & --- & $73 \mathrm{cbd}$ & $68 \mathrm{bc}$ \\
\hline 15) CP EC+ Vapam & $130+420$ & 43 & $63 \mathrm{~b}$ & $99 \mathrm{~b}$ & 75 bcd & 87 def \\
\hline 16) CP EC & $130 / 200$ & 43 & $62 \mathrm{~b}$ & $96 \mathrm{~b}$ & $73 \mathrm{bcd}$ & 85 def \\
\hline 17) Untreated & 0 & --- & $0 \mathrm{a}$ & $0 \mathrm{a}$ & $0 \mathrm{a}$ & $0 \mathrm{a}$ \\
\hline
\end{tabular}

${ }^{2}$ Weed control by the fumigants was calculated as percentage of weed biomass reduction relative to the untreated control.

yetailed results on the efficacy of alternative fumigants to control specific weed species were published by Fennimore et al. (2003).

${ }^{\mathrm{x}}$ Units are $\mathrm{kg} \cdot \mathrm{ha}^{-1}$.

wercentages followed by the same letter in each column are not significantly different at $P<0.05$ (statistical analysis was performed using the actual weed mass data). 
$61 \mathrm{~L} \cdot \mathrm{m}^{-2}$ (87 and $98 \mathrm{mg}$ 1,3-D/L air) than with

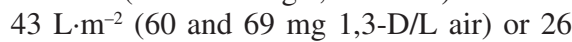
$\mathrm{L} \cdot \mathrm{m}^{-2}$ (37 and $42 \mathrm{mg}$ 1,3-D/L air ) irrigation water. Although the concentration of 1,3-D in the largest amount of water may appear inadequate, our studies suggest that the large amount of irrigation water $\left(>40 \mathrm{~L} \cdot \mathrm{m}^{-2}\right)$ better delivers fumigants to the target soil volume and reduces fumigant volatilization losses during and after application (Fig. 1). The embossed PE mulch used in this study obviously did not prevent or reduce fumigant volatilization losses, and water was the only true seal. Application of a large volume of water also reduced the gas-phase diffusion in soil and reduced volatilization losses. However, in many soils (coarse-textured or clayey soils), beds can become unstable and collapse with large water applications, and bed stability may constrain water application to under $50 \mathrm{~L} \cdot \mathrm{m}^{-2}$.

The efficacy of $\mathrm{CP}$ on soilborne pathogenic fungi is well documented (Wilhelm, 1999); however, little information is available on $\mathrm{CP}$ efficacy when applied through the drip irrigation systems. Research conducted on the same soil in Watsonville determined that a minimum of $140 \mathrm{~kg} \cdot \mathrm{ha}^{-1}$ application rate of CP applied by shank injection is needed for effective control of Verticillium dahliae at $15 \mathrm{~cm}$ depth, but 224 $\mathrm{kg} \cdot \mathrm{ha}^{-1}$ is required for control at $50 \mathrm{~cm}$ depth (Duniway, 2002). In other experiments, Duniway et al. (2001) found that CP EC applied at $278 \mathrm{~L} \cdot \mathrm{ha}^{-1}$ was as effective as $371 \mathrm{~L} \cdot \mathrm{ha}^{-1}$ of InLine in controlling soil pathogens to $30 \mathrm{~cm}$ depth. Our results suggest that $130 \mathrm{~L} \cdot \mathrm{ha}^{-1}$ may not be adequate to control soilborne pathogens and a minimum of $200 \mathrm{~L} \cdot \mathrm{ha}^{-1}$ applied in 43 $\mathrm{L} \cdot \mathrm{m}^{-2}$ is required to produce strawberry yield equivalent to standard $\mathrm{MB}: \mathrm{CP}$ fumigation (Table 4), especially when soil infestation by verticillium wilt is high. Although application of CP EC alone in different amounts of water was not evaluated in our study, it is expected that a larger amount of water would provide better fumigant distribution in soil, and possibly better pathogen control. Similar studies on CPEC use for tomato production confirmed that the efficacy of CP EC was affected by the volume of application water more than the application rate or concentration (Gullino et al., 2002). These studies found that $20 \mathrm{~g} \cdot \mathrm{m}^{-2}$ $\left(200 \mathrm{~kg} \cdot \mathrm{ha}^{-1}\right)$ of CP EC is more effective in controlling pathogens when applied in $30 \mathrm{~L} \cdot \mathrm{m}^{-2}$ of water $\left(660 \mu \mathrm{g} \cdot \mathrm{L}^{-1}\right)$ than when applied in 20 $\mathrm{L} \cdot \mathrm{m}^{-2}$ of water $\left(990 \mu \mathrm{g} \cdot \mathrm{L}^{-1}\right)$. These studies also reported that for any application rate of $\mathrm{CP}$, drip fumigation was more efficacious than shank injection, especially in soils containing high amounts of organic matter.

Metam sodium use as a stand-alone fumigant for strawberry production in California has been limited because yields are generally lower than those obtained with MB:CP (Duniway, 2002). However, varying degrees of success have been recently reported for strawberry production in Europe (Cebolla, 2002; Rabasse, 2002). Metam sodium and its active derivatives are not very mobile in soil and proper application techniques are crucial for good efficacy of this fumigant to reduce pathogenic fungal populations in soil. The poor control of Fusarium oxysporum by metam sodium has been attributed to insufficient fumigant distribution in soil (McGovern et al., 1998). These authors also reported enhanced disease incidence in the metam sodium treated soils, possibly due to a reduction of naturally occurring microorganisms in combination with inadequate elimination of the pathogen. However, a combination of metam sodium (468 $\left.\mathrm{L} \cdot \mathrm{ha}^{-1}\right)$ and Telone C17 (126 L $\left.\cdot \mathrm{ha}^{-1}\right)$ provided good control of most soil pests and produced good yields in tobacco and pepper transplant production (Csinos et al., 1997).

In our studies, the simultaneous drip application of Vapam HL and InLine or CP EC in years 1 and 2 did not control verticillium wilt in the severely infested Watsonville soil. In addition, the weed control efficacy was diminished at both locations. The poor efficacy in these combination treatments was due to rapid degradation of CP EC and 1,3-D with Vapam HL (metam sodium) in the application water, and therefore reduced the fumigant efficacy to control soil pathogens (Trout and Ajwa, 1999). No information is available on the compatibility of CP and 1,3-D with metam sodium. Experiments conducted in our laboratory using gas chromatography found that $>50 \%$ of $\mathrm{CP}$ or 1,3-D degrade within a few hours after their addition into water containing an equivalent concentration of metam sodium. Therefore, these combination treatments were modified in year 3; they were applied sequentially where Vapam HL was applied $6 \mathrm{~d}$ after drip fumigation with InLine or CP. The sequential drip combination treatments provided the greatest yields in year 3 even with reduced application rates. Although results on the sequential application were obtained for only one growing season during this research, several on-farm demonstration trials between 1999 and 2003 showed that sequential application of reduced rates (60\% to $75 \%$ of recommended label rates) produce equivalent yields to standard MB:CP fumigation (Ajwa et al., 2003).

Haar et al. (2003) found that $1000 \mu \mathrm{M}(164$ $\mathrm{mg} \cdot \mathrm{L}^{-1}$ ) of $\mathrm{CP}$ in the soil air space (equivalent to a field application rate of $112 \mathrm{~kg} \cdot \mathrm{ha}^{-1}$ ) of a closed system killed $90 \%$ of common purslane and common chickweed weed seeds in $<1.5 \mathrm{~h}$ exposure time, but $28 \mathrm{~h}$ were needed to kill prostrate knotweed (Polygonum aviculare) seeds. In our studies, total 1,3-D and CP concentrations in the gaseous phase of soil were sufficient to control most weed seeds in the middle of the soil bed, but were insufficient to control weeds at the edge of the bed (Fig. 2). Fennimore et al. (2003) evaluated weed control in these and other plots and found that CP EC at $200 \mathrm{~L} \cdot \mathrm{ha}^{-1}$ and InLine at 236 to $393 \mathrm{~L} \cdot \mathrm{ha}^{-1}$, each applied singly, controlled weeds as well as MB:CP at 425 $\mathrm{kg} \cdot \mathrm{ha}^{-1}$. Weed control by InLine and CPEC was similar to MB:CPfor little mallow and prostrate knotweed seed buried at the center of the soil bed. The percentage of weed seed survival at the edge of the bed, however, was higher than in the middle of the bed due to lower fumigant concentrations at the bed edge. In addition, they also found that sequential application of Vapam HLafter InLine or CPEC did not always provide additional weed control benefit.
Although the sequential drip application of fumigants did not always provide additional weed control in raised bed culture (Fennimore et al., 2003), application of fumigant combinations might be needed to maintain the efficacy of 1,3-D or CP, especially after multiple applications to the same soil. Studies reported that repeated applications of a single fumigant (1,3-D and MITC) resulted in decreased efficacy to control soilborne pathogens (Di Primo et al., 2003; Verhagen et al., 1996; Warton and Matthiessen, 2000). These studies claimed that the diminished efficacy with repeated applications of a fumigant is related to a rapid microbial degradation due to a build-up of soil microbial populations that are able to survive and degrade that fumigant. Further research is needed to evaluate the best order of fumigant application or to develop fumigant rotation practices to prevent enrichment of microbial populations in soils that are able to degrade fumigants.

\section{Conclusions}

The most promising and cost-effective registered chemical alternatives to $\mathrm{MB}: \mathrm{CP}$ fumigation in strawberry production in California are mixtures of 1,3-D and CP applied in combination with metam sodium. Drip fumigation with InLine $\left(393 \mathrm{~L} \cdot \mathrm{ha}^{-1}\right)$ and CP EC $\left(300 \mathrm{~L} \cdot \mathrm{ha}^{-1}\right)$ or with reduced $(60 \%)$ rates of these fumigants followed by metam sodium $\left(420 \mathrm{~L} \cdot \mathrm{ha}^{-1}\right)$ controlled soilborne pathogens and weeds and produced strawberry yields comparable to production with $\mathrm{MB}: \mathrm{CP}$. Eight on-farm demonstration plots conducted between the years 1999 and 2002 confirmed that the sequential drip application using $60 \%$ of the label rates (Vapam HL after InLine or $\mathrm{CPEC}$ ) produced yields equivalent to $\mathrm{MB}: \mathrm{CP}$ (data not shown). This sequential application has become the choice of strawberry growers who are adopting drip fumigation. In 2003, $>20 \%$ of the California strawberry production fields were drip fumigated with the alternative fumigants. The current cost of the sequential drip application (InLine or CP EC followed by metam sodium) is one-half of the current MB: $\mathrm{CP}$ standard fumigation cost. Drip fumigation is desirable because it is safer than present methods of shank injection; workers are not required to be in the field during application. However, it will require good irrigation systems and dependable injection equipment.

To achieve good lateral distribution of fumigants, large amounts of irrigation water $\left(50 \mathrm{~L} \cdot \mathrm{m}^{-2}\right)$ may be needed for sandy loam and loamy soils. Greater concentrations of fumigants with large amounts of water suggest that water reduces fumigant volatilization losses by increasing the amount of fumigant in the water phase and reducing the total air space available for fumigant diffusion in soil. Application of fumigants in small amounts of water results in poor fumigant distribution and high volatilization losses that diminish the efficacy to control soilborne pathogens and therefore, lower strawberry yield. In very coarse-textured or clayey soils, beds can become unstable and collapse with large water applications, and bed 
stability may limit the volume of water that can be applied. Also, the amount of application water may not have a significant effect on fumigant distribution in sandy and loamy sand soils due to limited lateral water movement in these soils. Further research is needed to determine optimum application parameters for various soil types.

\section{Literature Cited}

Ajwa, H.A., T. Trout, J. Mueller, S. Wilhelm, S.D. Nelson, R. Soppe, and D. Shatley. 2002. Application of alternative fumigants through drip irrigation systems. Phytopathology 92:1349-1355.

Ajwa HA, S. Fennimore, Z. Kabir, F. Martin, J. Duniway, G. Browne, T. Trout, R. Goodhue, and L. Guerrero. 2003. Strawberry yield under reduced application rates of chloropicrin and Inline in combination with metam sodium and VIF, p. 2. In: Proceedings Annual International Research Conference on methyl bromide alternatives and emissions reductions. 3-6 Nov. 2003, San Diego, Calif. http://www.mbao.org/.

Baines, R.C., R.H. Small, T.A. DeWolfe., J.P. Martin, and L.H. Stolzy. 1957. Control of the citrus nematode and Phytophthora spp. by Vapam HL. Plant Dis. Rpt. 41:405-414.

Ben-Yephet, Y. and Z.R. Frank. 1985. Effect of soil structure on penetration by metam-sodium and of temperature on concentrations required to kill soilborne pathogens. Phytopathology 75:403-406

California Environmental Protection Agency. 2001. Pesticide use report. Calif. EPA, Dept. of Pest. Regulat., Info. Syst. Branch, Sacramento. http://www.cdpr.ca.gov/docs/pur/pur01 rep/ trends01.pdf.

California Environmental Protection Agency. 2002 Recommended permit conditions for using 1,3dichloropropene pesticides (fumigant). Calif. EPA, Dept. of Pesticide Regulat., Sacramento. http://www.cdpr.ca.gov.

California Strawberry Commission. 2003. Strawberries Review. http://www.calstrawberry.com.

Cebolla V. 2002. Alternatives to methyl bromide in vegetable and strawberry crops in Spain, $\mathrm{p}$. 61-65. In: Proceedings international conference on alternatives to methyl bromide. Sevilla, Spain.

Csinos, A.S., W.C. Johnson, A.W. Johnson, D.R. Sumner, R.M. McPherson, and R.D. Gitaitis. 1997. Alternative fumigants for methyl bromide in tobacco and pepper transplant production. Crop Protection 16:585-594.

Di Primo P, G. Abraham, M. Austerweil, B. Steiner, M. Beniches, I. Peretz-Alon, and J. Katan. 2003. Accelerated degradation of metam-sodium and Dazomet in soil: Characterization and consequences for pathogen control. Crop Protection 22:635-646.

Duniway J.M. 2002. Status of chemical alternatives to methyl bromide for preplant fumigation of soil. Phytopathology 92:1337-43.

Duniway JM., J.J. Hao, D.M. Dopkins, H. Ajwa, and G.T. Browne. 2001. Chemical, cultural, and biological alternatives to methyl bromide for strawberry, p. 41. In: Annual International Research Conference on methyl bromide alternatives and emissions reductions, Calif. http://www.mbao.org/.

EXTOXNET-CP. 2001. Pesticide information
profile-Chloropicrin. Extension Toxicology Network. Available online at: http:pmep.cce. cornell.edu/profiles/extonet/carbaryl-dicrotophos/chloropicrin-ext.html.

EXTOXNET-MB. 2001. Pesticide information profile-Methyl bromide. Extension Toxicology Network. Available online at: http:pmep.cce. cornell.edu/profiles/extonet/haloxyfop-methylparathion/methyl-bromide-ext.html.

Fennimore, S.A., M.J. Haar, and H.A. Ajwa. 2003. Weed control in strawberry provided by shankand drip-applied methyl bromide alternative fumigants. HortScience 38:55-61.

Gan, J., S.R. Yates, D. Wang, and F.F. Ernst. 1998. Effect of application methods on 1,3-dichloropropene volatilization from soil under controlled conditions. J. Environ. Quality. 27:432-438.

Gullino, M.L., A. Minuto, G. Gilardi, A. Garibaldi, H. Ajwa, and T. Duafala. 2002. Efficacy of preplant soil fumigation with chloropicrin for tomato production in Italy. Crop Protection 21:741-749.

Haar, M.J., S.A. Fennimore, H.A. Ajwa, and C.Q. Winterbottom. 2003. Chloropicrin effect on weed seed viability. Crop Protection 22:109-115.

Jaworski, C.A., S.M. McCarter, A.W. Johnson, and R.E. Williamson. 1978. Response of onions grown for transplants to soil fumigation. J. Amer. Soc. Hort. Sci. 103:385-388.

Johnson, A.W. and J. Feldmesser. 1987. Nematicides-A historical review, p. 448-454 In: J.A. Veech and D.W. Dickson (ed.).Vistase on nematology. Soc. Nematol., Hyattsville, Md.

Johnson, A.W., S.M. McCarter, C.A. Jaworski, and R.E. Williamson. 1979. Chemical control of nematodes and soilborne plant-pathogenic fungi on cabbage transplants. J. Nem. 11:138-144.

Kasperbauer, M.J. 2000. Strawberry yield ove red versus black plastic mulch. Crop Sci. 40:171-174.

Lakes Environmental Software. 2000. 1,3-dichloropropene fact sheet. Lakes Environmental Software. http://lakes-environmental.com. toxic/1_3-dichloropropene.html.

Lembright, H.W. 1990. Soil fumigation: Principles and application technology. J. Nematol. 22(Suppl.):632-644.

Locascio, S.J., J.P. Gilreath, D.W. Dickson, T.A Kucharek, J.P. Jones, and J.W. Noling. 1997. Fumigant alternatives to methyl bromide for polyethylene-mulched tomato. HortScience 32:1208-1211.

Martin, F.N. 1992. The genus Pythium, p. 39-49. In L. Singleton et al. (eds.). Methods for research on soil borne phytopathogenic fungi. Amer. Phytopathol. Soc., St. Paul, Minn.

McKenry, M.V. 1999. The replant problem and its management. Catalina Publ., Fresno, Calif.

McCarter, S.M., C.A. Jaworski, and A.W. Johnson. 1978. Effect of continuous plant culture and soil fumigation on soilborne plant pathogens and on growth of tomato transplants. Phytopathology 68:1475-1481

McGovern, R.J., C.S. Vavrina, J.W. Noling, L.A. Datnoff, and H.D. Yonce. 1998. Evaluation of application methods of metam sodium for management of fusarium crown and root rot in tomato in southwest Florida. Plant Dis. 82:919-923.

McNiesh, N.C. Welch, and R.D. Nelson. 1985. Trickle irrigation requirements for strawberries in coastal California. J. Amer. Soc. Hort. Sci. 110:714-718
Nicot, P.C. and D.I. Rouse. 1987. Precision and bias of three quantitative soil assays for Verticillium dahliae. Phytopathology 77:875-881.

Noling, J. W. and J.O. Becker. 1994. The challenge of research and Extension to define and implement alternative to methyl bromide. J. Nematol. 26(Suppl.):573-586.

Rabasse JM. 2002. Metam sodium on strawberry: Example of commercial replacement of methyl bromide in Spain and France, p. 27. In: Proceedings Annual International Research Conference on Methyl Bromide Alternatives and Emission Reductions

Roberts, P.A., A.C. Magyarosy, W.C. Matthews, and D.M. May. 1988. Effects of Metam-sodium applied by drip irrigation on root-knot nematodes Pythium ultimum and Fusarium sp. in soil and on carrot and tomato roots. Plant Dis. 72:213-217.

Shaw, D.V., W.D. Gubler, K.D. Larson, and J. Hansen. 1996. Genetic variation for field resistance to Verticillium dahliae evaluated using genotypes and segregating progenies of California strawberries. J. Amer. Soc. Hort. Sci. 121:625-628.

Smelt, J.H., M. Leistra, M.C. Sprong and H.M. Nollen. 1974. Soil fumigation with dichloropropene and metham-sodium: Effect of soil cultivations on dose pattern. Pest. Sci. 4:419-428.

Trout, T., and H.A. Ajwa. 1999. Strawberries: drip irrigation and the promise of alternative fumigants. Irr. J. 49:6-7.

United Nations Environment Programme. 1997. Report of the 9th Meeting of the Parties to the Montreal Protocol on Substances that Deplete the Ozone Layer. Montreal, Canada

United States Environmental Protection Agency. 1993. Protection of stratospheric ozone. Fed. Reg. 58:15,014-15,049.

United States Department of Agriculture. 2003. National Agricultural Statistics Service. http:// www.usda.gov/nass/pubs/agstats.htm.

Verhagen C, G. Lebbink, and J. Bloem. 1996. Enhanced biodegradation of the nemadicides 1,3-dichloropropene and methyl isothiocyanate in a variety of soils. Soil Biology \& Biochemistry 28:1753-1756.

Warton B, and J.N. Matthiessen. 2000. Enhanced biodegradation of metam sodium soil fumigant in Australia, p. 377-380. Proceedings of the BCPC Conference-Pests and Diseases 2000. 4C-4.

Watson, R.T., D.L. Albritton, S.O. Anderson, and S.E. Bapty. 1992. Methyl bromide: Its atmospheric science, technology, and economics. Montreal Protocol Assessment, United Nations Environ. Program, Nairobi, Kenya.

Wilhelm, S., R.C. Storkan, and J.E. Sagen. 1961. Verticillium wilt of strawberry controlled by fumigation of soil with chloropicrin and chloropicrin-methyl bromide mixtures. Phytopathology 51:744-748.

Wilhelm, S. and A.O. Paulus. 1980. How soil fumigation benefits the California strawberry industry. Plant Dis. 64:264-270

Wilhelm, S. and R.C. Storkan. 1990. Large scale soil fumigation growth response. Phytopathology 49:530-531.

Wilhelm, S, and F.V. Westerlund. 1994. Chloropicrin-Soil fumigant. Calif. Strawberry Comm., Watsonville.

Wilhelm, S. 1999. The California strawberry industry and soil fumigation. A Review. Calif. Strawberry Comm., Watsonville. 